\title{
CrimRxiv
}

\section{Combatting Illicit Trade on the EU Border: A Comparative Perspective}

\section{Celina Nowak}

Published on: Jul 01, 2021

DOI: $10.21428 / c b 6 a b 371.0 b d 68 e 7 c$

License: Creative Commons Attribution 4.0 International License(CC-BY 4.0). 
